Cahiers $d u$ MONDE RUSSE

\section{Cahiers du monde russe}

Russie - Empire russe - Union soviétique et États indépendants

48/2-3 | 2007

Les résonances de 1905

\title{
Pamjat'o Pervoj rossijkoj revoljucii v 1917 godu.
}

\author{
Boris I. KOLONICKIJ
}

\section{OpenEdition \\ Journals}

Édition électronique

URL : https://journals.openedition.org/monderusse/9024

DOI : 10.4000/monderusse. 9024

ISSN : $1777-5388$

Éditeur

Éditions de l'EHESS

Édition imprimée

Date de publication : 15 avril 2007

Pagination : $519-538$

ISBN : 978-2-7132-2147-7

ISSN : $1252-6576$

\section{Référence électronique}

Boris I. KOLONICKIJ, « Pamjat'o Pervoj rossijkoj revoljucii v 1917 godu. », Cahiers du monde russe [En ligne], 48/2-3 | 2007, mis en ligne le 01 janvier 2007, consulté le 03 septembre 2022. URL : http:// journals.openedition.org/monderusse/9024; DOI : https://doi.org/10.4000/monderusse.9024 
chercher : repérer : avancer

Cet article est disponible en ligne à l'adresse :

http://www.cairn.info/article.php?ID REVUE=CMR\&ID NUMPUBLIE=CMR 482\&ID ARTICLE=CMR 4820519

\title{
Pamjat’o Pervoj rossijkoj revoljucii v 1917 godu
}

\author{
par Boris I. KOLONICKIJ
}

\section{Editions de I'EHESS | Cahiers du monde russe}

\author{
2007/2-3 - Vol 48 \\ ISSN 1252-6576 | ISBN 9782713221477 | pages 519 à 538
}

Pour citer cet article :

-I. KOLONICKIJ B., Pamjat' o Pervoj rossijkoj revoljucii v 1917 godu, Cahiers du monde russe 2007/ 2-3, Vol 48, p. 519-538.

Distribution électronique Cairn pour les Editions de l'EHESS.

(C) Editions de l'EHESS. Tous droits réservés pour tous pays.

La reproduction ou représentation de cet article, notamment par photocopie, n'est autorisée que dans les limites des conditions générales d'utilisation du site ou, le cas échéant, des conditions générales de la licence souscrite par votre établissement. Toute autre reproduction ou représentation, en tout ou partie, sous quelque forme et de quelque manière que ce soit, est interdite sauf accord préalable et écrit de l'éditeur, en dehors des cas prévus par la législation en vigueur en France. Il est précisé que son stockage dans une base de données est également interdit. 


\section{БОРИС И. КОЛОНИЦКИЙ}

\section{ПАМЯТЬ О ПЕРВОЙ РОССИЙСКОЙ РЕВОЛЮЦИИ В 1917 ГОДУ:}

\section{Случаи Севастополя и Гельсингфорса}

В последнее время все чаще употребляются понятия «социальная память», «культура памяти», «коллективная память». Историков интересуют проблемы формирования и ре-интерпретации образов прошлого, их закрепления, замещения и подавления.

Между тем историки России пока не очень активно используют этот подход. Отчасти это объясняется здоровым скептицизмом по отношению к «модному направлению» (если можно назвать «модным» подход, развивающийся уже на протяжении пары десятилетий). Сомнения вызывает и нестрогий, метафоризированный понятийный аппарат, использующийся в некоторых соответствующих исследованиях.

Однако, представляется, изучение исторической памяти в отдельных случаях весьма плодотворно. В частности, оно может обогатить исследование политической истории.

Ниже рассматривается вопрос о том, как память о революции 1905 г. была инструментализирована в 1917 г.

Очевидно, что «политика забвения» была важным элементом официальной политики памяти империи о событиях 1905 года. Так, военные корабли, участвовавшие в событиях революции, царское правительство лишало названий, «опозоренных» мятежами: броненосец «Князь ПотемкинТаврический» стал тогда «Пантелеймоном», крейсера «Очаков» - «Кагулом», «Память Азова» - «Двиной». 
С другой стороны, устанавливались памятники деятелям режима, жертвам революционного террора и простым военнослужащим, погибшим от рук революционеров.

Свою версию памяти о революции 1905 года предлагала субкультура радикальной интеллигенции. Например, в кабинете адвоката левых взглядов А.Ф. Керенского находились некие сувениры, напоминавшие о восстании лейтенанта П.П. Шмидта (по всей видимости, это было какое-то изображение) $)^{1}$.

Официальная политика памяти и политика забвения подвергались сомнениям не только со стороны оппозиционных политических партий. Известное развитие получила «народная», фольклорная память. Для этой памяти было характерно преувеличение масштаба и характера правительственных репрессий во времена Первой революции. Эти представления отразились в публицистике 1917 года. Процитируем газету партии социалистовреволюционеров: «Моряки не забыли тысячи своих товарищей, погибших в 1905-1906 гг. в Балтийском и Северном морях. Когда их, сажая по тысяче человек и больше в одну баржу, отвозили в залив и, расстреливая баржу вместе с истинными защитниками интересов трудового народа - топили в пучине залива...»²

Подобная память повлияла на весьма жестокое отношение многих восставших матросов к офицерам, что первоначально особенно проявилось на Балтийском флоте, в Кронштадте и Гельсингфорсе. Самосознание коллективной жертвы становилось важным источником мобилизации. Виктимизация оправдывала и оформляла крайнюю агрессивность рядовых моряков, доходящую до садизма.

Ряд моряков оправдывал свои жестокие действия, прямо ссылаясь на правительственные репрессии 1905-1907 годов. Напоминание о павших «борцах за свободу» было важным ресурсом политической мобилизации. Матрос Чугунов писал вскоре после свержения монархии: «<..> неужели мы запятнаем наш дорогой флот, тот флот, который первым поднял знамя революции в 1905 году? <..> неужели мы осрамим память наших дорогих покойников, которые приняли венец мучеников и были живьем сожжены на баржах» ${ }^{3}$.

После Февраля первые коммеморативные мероприятия новых властей были своеобразной реакцией на политику памяти и политику забвения старого режима. Так, смена названий военных кораблей в 1917 году провоцировалась более ранней «ономастической контрреволюцией». После выступлений ряда команд приказом по Морскому министерству от 31 марта этим судам возвращались старые названия, которые воспринимались в новой ситуации

1. R. Abraham, Alexander Kerensky: The First Love of the Revolution, New York : Columbia University Press, 1987, p. 50.

2. Народная Нива, Гельсингфорс, 1917, 15 (28) июля.

3. Известия Гельсингфорсского Совета депутатов армии, флота и рабочих Свеаборгского порта, 1917, 29 марта. 
как «революционные». Некоторое исключение было сделано для знаменитого броненосца: титул «князь» звучал «старорежимно» и корабль стал просто именоваться «Потемкин Таврический» ${ }^{4}$.

Однако моряки «Пантелеймона» не желала получать такое название: имя фаворита императрицы с их точки зрения не могло быть революционным символом. Команда направила послание в Севастопольский Совет:

В настоящее время, когда крейсер «Кагул» и линейный корабль «Екатерина Великая» получилисвоепросимое («Кагул»-«Очаков»,Екатерина -«Свободная Россия»), мы, пантелеймоновцы, получили совершенно нами нежеланное и непросимое - «Потемкин». Протестуем против этого дара и заявляем, что мы не расстанемся с нашим дорогим «Пантелеймоном» до тех пор, пока высшая власть не даст нам просимого названия «Борец за свободу», ибо «Пантелеймон» в настоящую войну имеет великие боевые заслуги, и может уступить только [в] заслуге нашему брату 1905 года, но не «Потемкину». Поэтому обращаемся в Центральный Исполнительный комитет с просьбой - довести до сведения об изложенном товарища морского министра о непризнании нами «Потемкина» и крайнем желании наименовать линейный корабль «Пантелеймон» только [в] «Борца за свободу», что просим осуществить в возможно кратчайший срок. ${ }^{5}$

И в этом случае Морское министерство пошло навстречу команде корабля. Уже 28 апреля 1917 г. броненосец получил название «Борец за свободу» ${ }^{6}$.

Политика памяти революционной эпохи 1917 г. имело и юридическое измерение. Так, суды выносили решения:

Освободить от последствий судимости (1907) и восстановить во всех правах «действовавших из политических побуждений».

Участники революции 1905 г. требовали наград, а люди, участвовавшие в подавлении восстаний, наград лишались. Так, 12 апреля Центральный Исполнительный комитет Севастопольского Совета направил предписание председателю судового комитета эскадренного миноносца «Счастливый»: «Предлагается секретно, безоглашения, предложить кондуктору Митрофанову снять Георгиевскую медаль, полученную им за усмирение команды в 1905 г., на крейсере "Память Азова"» 8

В некоторых случаях речь шла не только о лишении наград. Офицеры, подавлявшие восстания в эпоху первой революции порой арестовывались, отдавались под суд. Эти действия сопровождались общественной дискуссией о событиях 1905-1907 гг. Так, резолюция собрания матросов, солдат и рабочих в г. Севастополе, собравшихся во дворе Черноморского экипажа 1 октября, гласила: «<...> обсудив вопрос о членах Севастопольского военно-морского

4. Российский государственный архив Военно-морского флота (далее - РГА ВМФ), ф. 249, оп. 1, д. 103, л. 101.

5. РГА ВМФ, ф. Р-181, оп. 1, д. 43, л. 144.

6. РГА ВМФ, ф. 249, оп. 1, д. 103, л. 243.

7. Крымский вестник, Севастополь, 1917, 11 мая.

8. РГА ВМФ, ф. Р-181, оп. 1, д. 39, л. 31; д. 43, л. 45. 
суда генерал-лейтенанте фон-Кетцере, генерал-майоре Твердове, генералмайоре Федорове и подполковниках Богомольце и Фрязеновском признало их участниками палачей (!) Николая Романова, принимавших деятельное участие в приговаривании (!) к смертной казни и в каторжные работы борцов за свободу в 1905-м и в 1912-м годах постановило: 1) Требовать от исполнительного комитета Севастопольского Совета В. и Р. депутатов немедленно арестовать выше названных лиц $<\ldots>{ }^{9}$.

Однако политика памяти новых властей была не только реакцией на предшествующую политику старого режима. Во многих отношениях она определялась задачами конструирования новой революционной идентичности.

Историческое сознание революционных эпох определяется противоречивыми тенденциями. С одной стороны, революции стремятся считать себя началом новой эры, началом новой истории, неудивительно, что революции, вслед за Французской революцией XVIII века порой предлагают даже новое летоисчисление.

С другой стороны, самосознание революции пытается утвердить политические ценности, обращаясь к авторитету великих предшественников. С помощью новой политики памяти и новой политики забвения конструируется революционное прошлое, делающее новый режим легитимным.

Любая власть стремится упрочить свое положение с помощью практик коллективной мнемотехники. Так, после Февраля всталвопрос о созданииновых общенациональных праздников. Старые «царские» праздники, отменялись, Министерству внутренних дел поручалось выработать соответствующие предложения и представить их правительству. МВД 11 мая направило свой проект для обсуждения в Министерство народного просвещения. Планировалось установить три общенациональных праздника: 19 февраля, день освобождения крестьян от крепостной зависимости; 17 октября - «день установления в Российском Государстве первого конституционного строя» и 27 февраля - «в память Великой Российской революции, когда сам народ в лице Исполнительного комитета Государственной Думы взял власть в свои руки». Предложение МВД было направлено в министерства юстиции и народного просвещения, а также в Святейший Синод, все ведомства отнеслись к нему сочувственно ${ }^{10}$.

Как видим, чиновники Временного правительство пытались установить связь между революцией и российской либеральной традицией, важным «местом памяти» 1905 года был избран день подписания Манифеста 17 октября.

Но даже для части либералов подобная «родословная» нового государства выглядела недостаточно революционно. Весьма умеренная севастопольская газета писала: «Как в лучах солнца тонут лучи звезд, так в лучах этих дней -

9. Прибой, Гельсингфорс, 1917, 21 октября (3 ноября).

10. Российский государственный исторический архив, ф. 797, оп. 86, д. 21, л. 64; ф. 1284 , оп. 187 , д. 1 л. л. $1-11$. 
28 февраля-2 марта померкли и потонули дни 19 февраля и 17 октября» ${ }^{11}$. Очевидно, что свершившийся переворот рассматривался как совершенно уникальное событие.

В то же время левые силы возводили генеалогию революции к событиям революционного прошлого, здесь особую роль играла память о революции 1905 года, прежде всего память о вооруженных восстаниях, терроре и других формах активной борьбы со старым режимом.

Эта тенденция находила отзвук в массовом сознании. Показательно, что интерес к истории революционного движения нашел свое отражение и в выпуске кинофильмов в 1917 году. Фирмы А.Г. Талдыкина, «Акционерное общество И.Либкина», «А. Дранков и компания» предлагали зрителям ленты: «Азеф и Азефовщина», «Бабушка русской революции (Мученица за свободу)», «Борцы за свободу», «Георгий Гапон», «Солнце свободы (Слава борцам за свободу)» ${ }^{12}$. Революционная традиция пользовалась спросом, и рынок спешно этот спрос удовлетворял.

Популярностью пользовались и фильмы, посвященные восстаниям эпохи первой российской революции. В одной из газет Гельсингфорса сообщалось: «Выходя из кинотеатра по Унионской улице, где демонстрировалась картина «Смерть лейтенанта Шмидта»... (2 матроса и 3 солдата): «Видите, товарищи, как ваш брат армейская каша, дружно взяли на изготовку ружья для расстрела, не желающих расстрелять Шмидта матросов», - дружелюбно говорит один из матросов солдатам» ${ }^{13}$. «Дружелюбная» реплика моряка может быть лучше понята, если учесть, что в сухопутных частях данной базы большим влиянием пользовались социалисты-революционеры, а команды военных кораблей были настроены более радикально, поддерживая большевиков, левых эсеров и анархистов. Между солдатами и матросами возникло известное соперничество, и те и другие стремились обосновать давность участия своего рода оружия в освободительной борьбе. Ссылка на «свое» революционное прошлое «доказывала» справедливость современного политического курса.

Разные политические силы обращались к разным событиям и разным участниками политического процесса 1905 года.

Даже вопрос об определении времени начала первой революции приобретал немалое политическое значение. Так, пропагандисты партии социалистовреволюционеров связывали его с убийством министра внутренних дел Плеве: «15 июля 1917 года назначен день ПСР (партии социалистов-революционеров - Б.К.), потому что в этот день 1904 года рукой Егора Сазонова был убит министр Плеве, и в русской истории начался новый период- период беспощадной борьбы с царизмом, при конце которого мы присутствуем»,сообщал гельсингфорсский комитет партии ${ }^{14}$.

11. Крымский вестник, Севастополь, 1917, 7 марта.

12. Сине-фоно, № 11-12, с. 26-27, 35, 97; Великий кинемо: Каталог сохранившихся игровых фильмов России, 1908-1919, М., 2002. с. 364, 370.

13. Гр. Кононов, «С натуры», Прибой, Гельсингфорс, 1917, 6 (19) августа.

14. Народная Нива, Гельсингфорс, 14 (27) июля. 
Соответственно, сторонники партии эсеров призывали «довести до победного конца революцию, начатую 15 июля 1904 г.» и оправдаться «перед тенями наших дорогих, погибших в ссылке, тюрьмах, на эшафоте, под пулями царских палачей, товарищей» ${ }^{15}$. Очевидно, избрание такого «места памяти» социалистами-революционерами должно было способствовать укреплению авторитета партии.

Но лидеры левого, интернационалистского крыла партии социалистовреволюционеров не желали отдать революционное прошлое партии на откуп своим оппонентам. Напротив, террористический акт 1904 года рассматривался как призыв к наиболее радикальным политическим действиям в новых условиях. Газета левых эсеров писала: «На могилах революционеров не плачут. На них клянутся продолжать борьбу за освобождение, первыми жертвами которой они были. Егор Сазонов погиб за социализм. Благоговейно дорожа его памятью, мы должны довести до конца дело освобождения труда, не останавливаясь и не изменяя ему. Как не изменяли ему те славные борцы, среди которых светится и личность Егора Сазонова» ${ }^{16}$.

Ссылками на опыт 1905 года порой обосновывалась и антиклерикальная деятельность в 1917 году. Автор большевистской газеты писал: «<..> морские священники сыграли большую роль в 1905 и 6 годах в Кронштадте в aрестах матросов» ${ }^{17}$.

В то же время и некоторые священники считали нужным вспомнить тех представителей своего сословия, которые участвовали в революции 1905 г. Так, на съезде духовенства и мирян Орловской епархии, который происходил в мае 1917 г., было решено «почтить память» местного священника о. Высокопольского, сосланного в 1905 г. на каторжные работы, учреждением стипендии его имени ${ }^{18}$. Можно предположить, что в условиях революции часть духовенства конструировало революционную генеалогию своего сословия, стремясь повысить его политическую роль и, возможно, чтобы противостоять наступлению антиклерикализма.

Представители радикальных политических групп использовали память о революции для ограничения власти офицеров в армии и военно-морском флоте. В то же время некоторые представители офицерской корпорации боролись за свой авторитет, напоминая обществу об офицерах, участвовавших в революции. Так, морской офицер сообщал в редакцию севастопольской газеты о лейтенанте Борисе Николаевиче Никитенко, казненном в Кронштадте в 1906 г. ${ }^{19}$

15. Народная Нива, Гельсингфорс, 15 (28) июля.

16. Социалист-революционер, Гельсингфорс, 1917, 15 (28) июля.

17. Волна, Гельсингфорс, 1917, 12 (25) июля.

18. П.Г. Рогозный, «“Церковная революция” в Орловской епархии: К изучению социально-политической борьбы внутри Российской Православной Церкви после Февральской революции», Новая политическая история, Сб. научн. работ. Серия «Источник. Историк. История», СПб., 2004, вып. 4, с. 215.

19. А. Миткевич, сташий лейтенант, « Письмо редактору», Крымский вестник, Севас- 
Нижемырассмотрим вопрос отом, как историческаяпамятьиспользовалась различными политическими силами на двух главных базах Российского военно-морского флота - в Севастополе и Гельсингфорсе.

Культ героев «освободительного движения» получил особое распространение в Черноморском флоте. Началось движение по поиску неизвестных мест захоронений «борцов за свободу», казненных «старым режимом». Определенные инициативыпредпринимали различные организации, но наряду с ними свои раскопки производили различные энтузиасты, движение приобрело стихийный характер. Были найдены останки 11 матросов, расстрелянных в 1912 году. В Севастопольском Совете обсуждался вопрос о перезахоронении «жертв революции, казненных в 1912 году». Делегатское собрание 25 апреля высказалось большинством голосов за гражданские похороны. Но такое решение, по-видимому, вызвало протесты, и 29 апреля было решено «хоронить гражданскими похоронами, но и со священниками». Торжественное погребение состоялось в Севастополе 30 апреля ${ }^{20}$.

Исполнительный комитет Севастопольского Совета снарядил и специальную экспедицию на остров Березань, на котором были расстреляны лейтенант П.П. Шмидт и другие руководители восстания на крейсере «Очаков» в 1905 году. Туда было послано посыльное судно «Принцесса Мария» с отрядом моряков. 16 апреля этой экспедиции удалось обнаружить захоронение. Гробы с телами «очаковцев» 6 мая были доставлены сначала в Очаков, а на следующий день - в Одессу ${ }^{21}$. Наконец, останки «борцов за свободу» 8 мая были перевезены в Севастополь. Когда корабль входил в бухту, все корабли Черноморского флота приветствовали его салютом и приспустили кормовые флаги, оркестры играли «Коль славен...». На флагманском корабле был поднят сигнал: «Вечная память борцам за свободу, павшим в 1905 году». По настоянию родственников погибших решено было устроить «смешанные» похороны - «гражданско-религиозные». В панихиде участвовали высшие представители духовенства города, захоронение было произведено в Покровском соборе Севастополя. Похороны представляли собой яркую оборонческую демонстрацию: рядом с хоругвями, красными знаменами и портретами лейтенанта Шмидта несли лозунги «Победа над Германией - путь к братству народов». Портреты Шмидта были на многих красных знаменах ${ }^{22}$.

В организации похорон в Севастополе активную роль играло командование Черноморского флота во главе с адмиралом А.В. Колчаком, который использовал и эту торжественную церемонию для укрепления своего влияния

тополь, 1917, 11 мая.

20. В.К. Жуков, Черноморский флот в революции 1917-1918 г2, М., 1932, с. 21-24; РГА ВМФ, ф. Р-181, оп. 1, д. 15, л. 143, 144.

21. Фотографии, на которых изображалась перевозка гробов на корабле и торжественная встреча в Одессе были опубликованы в петроградском иллюстрированном журнале «Нива», Нива, Пг., 1917, № 21, с. 211, 212.

22. Крымский вестник, Севастополь, 1917, 11 мая, 26 мая; Жуков, Черноморский флот в революции..., с. 24-26. 
и распространения идей оборончества. Во время церемонии перезахоронения именно адмирал шел за гробом лейтенанта Шмидта ${ }^{23}$.

В соответствии с приказом адмирала Колчака имя Шмидта было присвоено клубу офицеров Черноморского флота ${ }^{24}$.

Итак, ради достижения тактических преимуществ Колчак, возможно неохотно, но активно и творчески способствовал развитию революционного культа лейтенанта Шмидта, наиболее известного «борца за свободу». Способствуя формированию подобной исторической памяти адмирал временно укреплял свой политический статус, но, вместе с тем, он создавал такие правила политической игры, которые затрудняли его конечную победу.

На Черноморском флоте был создан также особый Фонд имени Шмидта. Севастопольские чиновники, например, сдавали свои ордена в этот фонд ${ }^{25}$.

В некоторых оборонческих резолюциях командование флота изображалось как продолжатель дела революционеров 1905 года. Служащие станции Сокологорное, Южной железной дороги заявляли: «Гордимся и верим, что славные потомки Шмидта и Матюшенко приложат все силы и разум довести войну до победоносного конца и удержат вырванную из рук тиранов - свободу. Да здравствует славный Черноморский флот! Да здравствует адмирал Колчак! Да здравствует свободная Россия! Ура Черноморскому флоту и ее вождю адмиралу Колчаку!». Показательно, что газеты, сочувственно относившиеся к адмиралу, печатали такие воззвания ${ }^{26}$. Колчак воспринимался как славный продолжатель дела лейтенанта Шмидта. Вряд ли адмирал был в восторге от такой роли, однако отказываться от нее в сложившихся условиях было бы самоубийственно.

Весной 1917 года Черноморский флот был цитаделью оборонцев, которые пытались использовать авторитет местной революционной традиции для укрепления влияния в масштабах страны. Эта тема широко использовалась черноморской делегацией, организованной при поддержке Колчака, которая посетила Петроград, Москву, фронт с целью пропаганды военных усилий.

На одном митинге в Москве Ф. Баткин, лидер делегации, эффектно заявил: «Товарищи, мы те, у кого был лейтенант Шмидт, матрос Матюшенко и предательски казненные матросы». После его речи по предложению председателя, присутствующие вставанием почтили память погибших за свободу матросов Черноморского флота и лейтенанта Шмидта. Вся аудитория пела: «Вы жертвою пали в борьбе роковой <...» Корреспондент отмечал: «Впечатление потрясающее. Многие плачут...» ${ }^{27}$.

23. А.И. Верховский, На трудном перевале, М., 1959, с. 236; Крымский вестник, Севастополь, 1917, 11 мая.

24. И.Ф. Плотников, Александр Васильевич Колчак: Исследователь, адмирал, верховный правитель России, М., 2002, с. 70.

25. Крымский вестник, Севастополь, 1917, 11 мая.

26. Там же, 16 мая.

27. Там же, 7 мая. 
Правда, вскоре обострилась ситуация и в самом Севастополе. Тогда Черноморскаяделегацияприняла «Обращение Черноморскойделегацииковсем частям флота, гарнизона и рабочим Севастополя». В нем содержался призыв крепить дисциплину, при этом делегация вновь апеллировала к авторитету революционной традиции: «<... твердо верим, что идеи, заповеданные вам матросами Гладковым и Антоненко, кондуктором Частником и лейтенантом Шмидтом, святы и обязательны для всех вас $<\ldots>»^{28}$.

Важным «праздником свободы» стал визит в Севастополь А.Ф. Керенского, который также пытался стабилизировать ситуацию на военно-морской базе и использовал для этого революционную традицию.

Утром 17 мая Керенский в сопровождении Колчака прибыл из Одессы на миноносце. Над бухтой реяли гидропланы. Керенский поднялся на борт флагманского корабля, где его ожидали высшие военные и гражданские чины. Керенский произнес речь, в которой он восхвалял «боевые и революционные традиции Черноморского флота» (именно такие выражения он использовал в своем выступлении). Министр призывал: «Светлая память лейтенанта Шмидта ближе вам, чем кому-либо, и я уверен, товарищи, что вы до конца выполните ваш долг перед страной». Затем последовала приветственная речь Колчака. После этого Керенский «инкогнито» съехал на берег и посетил Покровский собор, чтобы поклониться праху лейтенанту Шмидту и его товарищей. Министр возложил Георгиевский крест на могилу Шмидта ${ }^{29}$.

При негативном отношении к орденам, получившим известное распространение уже в это время, возложение Керенским Георгиевского креста на могилу лейтенанта Шмидта воспринималось уже как кощунство: «<... тайно посещает могилу и вместо венка возлагает царские кресты, которые выдавались палачам Шмидта в 1905 году». В мемуарах же участников событий действия Керенского описывались и как недостойное подражание традициям «старого режима»: «<... п по примеру царей, он возложил Георгиевский крест на могилу лейтенанта Шмидта». ${ }^{30}$

И позже обращение к местной революционной традиции использовалось для укрепления оборонческих настроений. Так, будущий военный министр Временного правительства А.И. Верховский, игравший немалую роль в Севастополе в первые месяцы революции, обратился 25 мая к офицерскому делегатскому собранию базы. Он с удовлетворением отмечал, что «<... удалось поставить государственную идею в Севастополе на должную высоту, сделавшую Севастополь в 3-й раз светочем русской жизни: 1856 г. 1905 г. и теперь, когда мы сказали первое слово о спасении родины» ${ }^{31}$.

Память о Первой российской революции в различных местах весьма отличалась. Для многочисленных солдат и матросов войсковых и флотских

\section{8. Там же, 16 мая.}

29. Там же, 18 мая.

30. А.П. Платонов, Черноморский флот в революции 1917 года и адмирал Колчак, Л., 1925, с. 79; Жуков, Черноморский флот в революиии ..., с. 50.

31. Крымский вестник, Севастополь, 1917, 7 июня. 
частей, дислоцированных в Финляндии, важнейшим «местом памяти» была Свеаборгская крепость. Расположенная на островах вблизи Гельсингфорса (Хельсинки) крепость была символом военного присутствия Российской империи в Великом княжестве.

В июле 1906 г. в крепости вспыхнуло восстание. Главной силой восставших были роты 1-го полка Свеаборгской артиллерии, к ним присоединились солдаты и моряки ряда других подразделений, а также финская Красная гвардия. В артиллерийских подразделениях давно нарастала напряженность. Повод создавала задержка демобилизации старших возрастов, ухудшение вещевого снабжения, слухи о злоупотреблениях интендантов и строевых офицеров. В гарнизоне возникли нелегальные кружки, которыми руководили некоторые офицеры, они были связаны с организациями социалдемократов и социалистов-революционеров. Роспуск Государственной думы, призыв трудовиков и социал-демократов к вооруженной борьбе спровоцировали восстание, которое с точки зрения политического подполья было преждевременным. Восставшие захватили ряд островов, их тяжелая артиллерия обстреливала острова, удерживавшиеся войсками, верными правительству. Переломом стало прибытие военных кораблей, которые с безопасной для них дистанции открыли огонь по батареям повстанцев. Многие восставшие бежали с островов, которые были заняты пехотой.

Руководители восстания, в том числе офицеры А. Емельянов и Е. Коханский, были осуждены военным судом и расстреляны 22 июня на Лагерном острове. Затем были осуждены еще две группы повстанцев.

Пленения и расстрела избежал один из руководителей нелегальных кружков Сергей Анатольевич Цион. В последующие годы он выступал в роли главного хранителя памяти о восстании. Уже в 1907 году в Гельсингфорсе была выпущена брошюра, в которой он излагал свою версию событий.

Впоследствии Цион эмигрировал, он жил в Западной Европе, поддерживал отношения с видными деятелями социалистического движения Франции и Великобритании.

В 1917 году разные силы по-разному вспоминали события 10-12-летней давности. Для многих солдат и, особенно, матросов особая память о том времени оправдывала жестокое поведение по отношению к генералам и адмиралам. В большевистской прессе публиковались письма военнослужащих, которые, например, пытались объяснить убийство в дни Февральской революции адмирала А.И. Непенина, командовавшего Балтийским флотом, как его жестокостью (действительной, или приписываемой ему), так и исторической памятью: «Вспомните, сколько было восстаний и все они во флоте, во флоте. Сколько вешали, сколько гнило по тюрьмам, сколько расстреливали в Кронштадте в 1905 и 1906 годах, со связанными проволокой руками, матросов грузили целыми баржами, вывозили в залив и пущенной миной с миноносца превращали все в кровавую пыль. Сколько потоплено так в заливе, что и могил их, если бы мы и хотели почтить их, не найдем. Владивосток, Севастополь, Петроград, Кронштадт, Ревель, Гельсингфорс, это все могилы лучших наших 
товарищей. Теперь на этих могилах, нашей «неорганизованностью» поднято знамя свободы», - писал матрос линейного корабля «Павел I» ${ }^{32}$.

Интересно, что моряк не упоминал Свеаборг, хотя он мог видеть островную крепость с борта своего корабля. Возможно, это было связано с тем, что во время этого восстания флот как раз выполнил «контрреволюционную» роль, что было не очень приятно вспоминать матросам в 1917 г.

Память о восстании в Свеаборге все же была необычайно важна для формирования особой революционной идентичности русских солдат и матросов в Гельсингфорсе. Многие с гордостью отмечали, что крепость стала важным, чуть ли не главным, уникальным местом памяти российской революционной традиции.

О событиях времен Первой российской революции упоминалось во время похорон повстанцев, погибших в марте 1917 г. Однако общественное мнение требовало более масштабных коммеморативных мероприятий. Местный активист писал в редакцию газеты: «Постановлением Гельсингфорсского Совета депутатов можно теперь же поручить составление истории восстания для возможно широкого распространения, определить место расстрела для постановки временного памятника, назвать батареи именами героев свеаборгского восстания 1906 года». Редакция поддержала мнение автора ${ }^{33}$.

Память о восстании 1906 г. была важна еще в одном отношении: воспоминания о совместных действий финских красногвардейцев и российских военнослужащих можно было использовать для совместных политических акций. При этом разные политические силы выделяли различные аспекты истории Первой революции. Большевики в большей степени, чем другие российские партии, проявляли солидарность с социал-демократами Финляндии. Поэтому В. Смирнов, например, на страницах большевистской газеты напоминал своим читателям о финской красной гвардии и ее легендарном руководителе капитане И. Коке ${ }^{34}$.

Хранителями же памяти о Свеаборгском восстании были, прежде всего, активисты партии социалистов-революционеров и артиллеристы 1-го полка (очевидно, что моряки и пехотинцы полков, подавлявших восстание, менее заинтересованы были в политическом использовании памяти о том событии).

Члены партии эсеров произвели разыскания и раскопки на Лагерном острове. Они обнаружили могилу с 24 захоронениями. Была обнаружена ленточка с матросской бескозырки, это, по мнению активистов, указывало на то, что могила принадлежит руководителям восстания ${ }^{35}$.

32. Волна, Гельсингфорс, 1917, 4 (17) апреля.

33. Известия Гельсингфорсского Совета депутатов армии, флота и рабочих Свеаборгского порта, 1917, 31 марта.

34. В. Смирнов, «По Финляндии. Красная Гвардия», Волна, Гельсингфорс, 1917, 10 (23) мая.

35. Народная Нива, Гельсингфорс, 1917, 26 апреля (9 мая). 
29 апреля на общем собрании группы сочувствующих ПСР прозвучало пожелание посетить всей группой братские могилы артиллеристов, матросов и минеров, «павших жертвою в борьбе за свободу 29 июля 1906 года». В воскресный день 30 апреля социалисты-революционеры организовали внушительную церемонию. Она была описана в статье «На дорогих могилах» и других заметках, опубликованных в местной эсеровской газете.

На Лагерный остров прибыли представители частей, участвовавших в восстании, других военнослужащих, их общее число составило примерно 2000 человек. Три оркестра попеременно играли революционные марши. Прозвучала марсельеза, затем, обнажив головы, похоронный марш. После этого собравшиеся троекратно пропели «Вечную память».

Затем выступил матрос, бывший свидетелем казни (он привозил столбы, к которым привязывали осужденных перед расстрелом). В своем выступлении оратор специально подчеркивал, что повстанцы отказались покаяться, сказав: «Помните, товарищи, что мы погибаем за свободу».

Один из артиллеристов рассказал о событиях 1906 г. «со слов очевидцев». Офицеру Емельянову, руководителю восстания приписывались предсмертные слова: «Здесь будет посеяно семя, а взойдет колос».

Другие ораторы призывали доказать, как участники революции ценят «братьев-учителей». Они требовали помочь семьям погибших, назначив им пожизненные пенсии (прозвучало предложение ради этого отобрать пенсии от жен министров).

Oсобое место в выступлениях заняла тема памяти. Прозвучала идея создания в Свободной России специального дня поминовения павших борцов за свободу. Предлагалось торжественно перезахоронить революционеров в более доступном и более почетном месте, соорудив внушительный памятник.

Участники церемонии дали клятву продолжить дело павших «борцов за свободу». Стоя на коленях, они слушали похоронный марш «Вы жертвою пали». Лейтмотивом выступлений ряда ораторов были слова: «Дорога, по которой шли павшие товарищи, была узенькая тропинка в терниях, но они открыли нам широкую дорогу, которая привела нас к свободе» ${ }^{36}$.

Очевидно, эта церемония повлияла на процесс создания специальных институтов памяти на военной базе. В тот же день, 30 апреля Гельсингфорсский Совет постановил образовать специальную комиссию по увековечению памяти «жертв освободительного движения» 1906 и 1907 года ${ }^{37}$. Член комиссии М.С. Степанов пытался собрать сведения о казненных участников восстания. Через прессу он обращался с призывом сообщать все сведения о «погибших от произвола товарищах» ${ }^{38}$. Очевидно, этот проект не был особенно удачным, в последующих публикациях большинство погибших называлось только по фамилиям.

36. Там же, 2 (15), 3 (16) мая.

37. Там же, 2 (15) мая.

38. Там же, 13 (26) мая. 
Отдельные подразделения вновь и вновь требовали переноса могил с островов «на более почетное место», и даже организовывали для этого денежные сборы. В эсеровской прессе вновь был возбужден этот вопрос. От Исполнительного комитета требовали выделения денег на финансирование перезахоронения и возведение памятника ${ }^{39}$.

Кпамятиовосстании 1906г.эсеровскаяпрессаГельсингфорсавозвращалась вновь и вновь. Летом местная газета опубликовала стихотворение капитана Аргамакова, посвященное памяти «борцов за свободу»:

В далекой чужбине, в сыпучих песках,

У самого синего моря

Вы спите. Отныне в народных сердцах

За то, что великого горя

Злой кубок дерзнули разбить вековой

Вы создали памятник свой.

Вы други неволей забытых (!) людей,

Им жертвуя лучшие годы,

И, смело восстав за трудящийся люд,

Потребовав землю и волю,

Свободным мечтали вы сделать их труд,

Сулили им светлую долю.

Так спите ж, борцы, благодарный народ

Оцкнит ваш труд благородный,

Ваш честный завет по дороге вперед

Избрал он звездой путеводной. ${ }^{40}$

Можно предположить, что офицер, публикуя подобное стихотворение на страницах газеты социалистов-революционеров, стремился укрепить свой авторитет в солдатской среде.

Подвиг павших героев вдохновлял и рядовых артиллеристов, также публиковавших свои стихи в эсеровской прессе. Рядовой Е.Шубин напечатал стихотворение «Свеаборг»:

Твои герои в грозных силах

Борьбу народную вели...

На их заброшенных могилах

Цветы свободы расцвели.

И те цветы, как плод из рая,

Ты для народа сохранишь;

Свои границы защищая,

За жизнь младую постоишь. ${ }^{41}$

Между тем в Гельсингфорс из эмиграции возвратился С.А. Цион, он сразу же включился в местную политическую жизнь, став через

39. Там же, 26 мая ( 8 июня).

40. Там же, 29 июня (12 июля).

41. Там же, 31 мая (13 июня). 
некоторое время председателем Обще-Финляндского комитета Партии социалистов-революционеров.

И свое участие в Первой Российской революции, и роль «хранителя памяти» о восстании 1906 года он использовал для борьбы за власть. В эсеровской прессе указывалось, что он «первый поднял знамя восстания в Свеаборге в 1905 году». Политическая деятельность в эмиграции также способствовала укреплению авторитета Циона. Отмечалось, что он является другом Лонгэ, членом Английской независимой рабочей партии. Подчеркивалось, что «скитаясь за границей, товарищ Цион много работал в области женского вопроса, а также в области аграрной реформы» ${ }^{42}$.

Цион выступал со своими воспоминаниями. Так, например, 25 июня в Александровском Русском театре состоялась его лекция на тему «Свеаборгское восстание и его значение для русской революции». В газете гельсингфорсских социалистов-революционеров печатались воспоминания Циона о восстании 1906 года ${ }^{43}$.

Эта тактика была довольно удачна. Используя свой авторитет «борца за свободу» Цион вытеснил левых эсеров из редакции местной газеты социалистов-революционеров «Народная нива» ${ }^{4}$.

События времен Первой российской революции Цион использовал и для обоснования политической линии умеренных социалистов в 1917 году. В своей лекции он так объяснял причины поражения восстания 1906 г.:

Причем разъединение произошло из-за того, что артиллеристы, не присоединяясь ни к какой политической партии, считали необходимым поднять восстание против правительства, так как дальше терпеть было нельзя. Матросы же, разделяя точку зрения артиллеристов относительно восстания, не поддержали их вовремя потому, что не получили указаний от ЦК партии с.-д., к которой они примыкали.

И вот это маленькое разногласие, маленькое недоразумение погубило все дело и этим отодвинуло зарю Русской свободы на целых 12 лет.

Не то мы видим в февральские дни нынешнего года, когда вся демократия поднялась как один человек, с единственной целью - с единственной целью низвергнуь старый, ненавистный всем царский режим... Это единение всех сил демократии вырвало из рук царизма главное средство его борьбы с революцией, заключавшееся в разъединении этих сил и направлении друг против друга, что имело место, когда матросы усмиряли тех, кого должны были поддержать...

Поэтому не будем же обострять отношений, не будем развивать разногласий, а постараемся найти общие средства, общие пути, которые объединили бы нас всех и повели бы к достижению наших целей, которые для всей русской

42. Там же, 1 (14) ноября.

43. Там же, 24 июня (7 июля), 9 (22), 11 (24), 12 (25), 14 (27), 15 (28), 16 (29) июля, 23 , 25 июля 28, (5, 7, 10 августа), 5 (18), 12 (25), 13 (26), 15 (28), 18 (31) августа.

44.. Там же, 24 июня (7 июля). 
демократии одни и те же - кончить войну и закрепить завоевания революции. Будем же помнить, что только в единении сила. ${ }^{45}$

Память о восстании была важна и для укрепления связи между солдатами и командным составом. Цион в своих воспоминаниях описывал события 1906 г. так:

$<\ldots>$ в этот вечер был заложен фундамент для будущих событий, имевших потом место в Свеабоорге, и заключен тот союз между свободными офицерами и свободными солдатами, благодаря которым через 12 лет Россия стала свободной. ${ }^{46}$

Этот прием, использование «уроков» 1906 г. для оценки современной политической ситуации, использовался пропагандой социалистовреволюционеров и позднее. Поражение восстания 1906 г. объяснялось партийными разногласиями, что обосновывало необходимость общенационального единства в революционной стране:

Большевики до самого момента восстания спорили, как они будут перестраивать Россию $<\ldots>$ когда Свеаборг восстал, они долго не решались дать соответствующие директивы Свеаборгскому флотскому экипажу и флоту, стоящему на рейде, а когда они появились, то было уже поздно. Разгром 1906 г. да послужит нам уроком. ${ }^{47}$

29 июня, в день полкового праздника 1-го артиллерийского полка, на Лагерном острове было устроено шествие к могилам погибших в 1906 г. Состоялся митинг, были возложены венки. Среди выступавших были, в частности, лидер эсеров Гельсингфорса и представитель финской Красной гвардии. На митинге выступил и Цион, избранный к этому времени командиром батальона артиллерийского полка. Он использовал событие для призыва к укреплению дисциплины: в тяжелое время поражения революции «одно давало бодрость героизма: осознание того, что «на этом самом месте, не где-нибудь, а на этом месте воссоздастся свободная армия, которая не пойдет расстреливать революционеров, а пойдет, если надо, умирать за революцию». Цион указывал на опасность контрреволюции и выражал уверенность, что «все» двинутся в случае нужды, независимо от партийных оттенков, «под знаменами, которые оставили нам наши товарищи, павшие под пулями царских палачей». Представитель британской независимой лейбористской партии рассказал присутствующим о святыне английского королевского военно-морского флота, могиле адмирала Нельсона. Но, продолжал он «... те славные борцы за свободу, перед могилами которых мы только что шли, отдали свою жизнь за нечто, что гораздо выше родины, за всеобщий мир, за свободу всего человечества». Неудивительно, что речь британского социалиста вызвала аплодисменты всех присутствующих. В заключении один русский оратор

\footnotetext{
45. Там же, 28 июня (11 июля).

46. Там же, 11 (24) июля.

47. Там же, 12 (25) июля.
} 
призвал организовать издание брошюр с портретами павших борцов, прибыль от продажи которых пойдет на памятник. Он также призвал привлечь к ответственности тех, кто участвовал в подавлении восстания, но не пришел в 1917 г. на помощь при розыске могил. В газете социалистов-революционеров печатался уточненный список казненных, однако многие из них были известны только по фамилиям ${ }^{48}$.

Упоминание об ответственности лиц, подавлявших восстание, могло прочитываться как угроза. Действительно, память о восстании 1906 года повлекла и политические репрессии. В воскресенье 2 июля Секцией по охране Народной свободы при Исполнительном Комитете Гельсингфорсского Совета были проведены аресты некоторых офицеров Свеаборгского гарнизона. Были арестованы: командир 1-го артиллерийского полка подполковник Кованько, начальник хозяйственной части 1-го артиллерийского полка подполковник Ларионов, начальник хозяйственной части артиллерийского склада Горюнов, представитель сухопутного фронта при штабе командующего флотом капитан Дудицкий, начальник электротехнического отделения капитан Мачигин, командир батальона 2-го артиллерийского полка капитан Бастамов, командир батальона 1-го артиллерийского полка, секретарь полкового комитета капитан Бастраков. Отмечалось, что эти офицеры «прославились» в 1906 г. как «подавители» восстания в Свеаборге и будут преданы гласному суду. Указывалось, что эти люди, «представляющие грозную контрреволюционную силу», были назначены на свои посты комендантом крепости ${ }^{49}$.

Затемвгазетепоявилосьсообщение обобстоятельствах, предшествовавших этому аресту. В секцию охраны Народной Свободы Гельсингфорсского Совета поступило заявление 8 роты 1-го Артиллерийского Свеаборгского полка с обвинением офицеров в активном участии в подавлении Свеаборгского восстания в 1906 г. Обвинение основывается на официальных документах рапортах арестованных офицеров, поданных ими по начальству об их личном участии в подавлении восстания. Заметка кончалась не очень понятным заключением: «Компрометирующие документы не имеются у некоторых, и эти, должно быть, будут освобождены в непродолжительном времени» ${ }^{50}$.

Однако вскоре солдаты 8-й роты направили в газету свое опровержение. Они утверждали, что арест был произведен Исполкомом Гельсингфорсского Совета накануне получения их заявления, а в своем заявлении рота вообе не требовала ареста этих офицеров, более того, имена их там не упоминались ${ }^{51}$.

В прессе появилось письмо, подписанное псевдонимом «Возмущенный». Автор утверждал, что арест офицеров был инспирирован Ционом, который тем самым сводил счеты со своими недругами, между тем как лица, принимавшие

48. Там же, 1 (14) июля.

49. Волна, Гельсингфорс, 1917, 5 (18) июля; Народная нива, Гельсингфорс, 5 (18) июля.

50. Народная нива, Гельсингфорс, 1917. 7 (20) июля.

51. Там же, 11 (24) июля. 
более активное участие в подавлении восстания 1906 г., остались на свободе. Цион в газете отвергал эти обвинения ${ }^{52}$.

Однако нельзя исключать возможность того, что Цион сыграл некую роль в арестах, стремясь укрепить свое положение в полку и в гарнизоне (показателен упрек в адрес коменданта).

В конце июля состоялась еще одна церемония, посвященная восстанию. 29 июля в день 11-й годовщины расстрела на Лагерном острове была устроена гражданская панихида, в которой участвовали представители исполнительных комитетов различных Советов и военнослужащие двух артиллерийских полков. Организаторы панихиды обеспечили специальный рейс парохода. К могилам были возложены венки, оркестр исполнил похоронный марш. После произнесения речей собравшиеся пропели похоронный марша и «Вечную память». Газета левых эсеров «Социалист-революционер» сообщала, что ораторы призывали «стоять на страже красного знамени социализма, которое было поднято 11 лет назад» ${ }^{53}$. Т.о. антимонархическое восстание рассматривалось как пролог социалистической революции. Память о восстании 1906 г. использовалась левыми социалистами для радикализации политического процесса.

В то же время явка на памятное мероприятие было знаком революционной лояльности. Сторонники социалистов-революционеров отмечали, что на нем присутствовало мало офицеров, явились лишь несколько офицеров и капитан Аргамаков (автор упоминавшегося стихотворения) $)^{54}$ Т.о. артиллерийские полки рассматривались как некое сообщество памяти, а неучастие в коммеморативной акции ставило под сомнение и политическую благонадежность, и полноправное участие в коллективе.

Политика памяти, проводившаяся прежде всего комитетами свеаборгских артиллеристов, вдохновляла и представителей других частей. Солдаты Владивостокского крепостного минного батальона, дислоцированного в Гельсингфорсе, в день батальонного праздника, также вспоминали участие своей части в событиях Первой российской революции. Они, как писал батальонный фельдшер Гладков, почтили память «великих борцов» «коленнопреклонением» и пением похоронного революционного гимна. Гладков предлагал вспомнить о могилах во Владивостоке, произвести сбор на устройство постоянного памятника (там уже был воздвигнут временный обелиск), навести справки, узнать фамилии павших товарищей, разузнать о местонахождении их семей и просить Временное правительство об обеспечении (материально) семей товарищей, павших в декабре 1907 года. В основу фонда на устройство памятника Гладков отчислял $10 \%$ своего жалования ${ }^{55}$.

52. Там же, 14 (27) июля.

53. Там же, 29 июля (11 августа); Социалист-революционер, Гельсингфорс, 1917, 5 (18) августа.

54. Народная нива, Гельсингфорс, 1917. 12 (25) августа.

55. Там же, 28 июля (10 августа). 
Тема исторической памяти вновь обострилась в Гельсингфорсе в период выборов в Учредительное собрание. Цион, кандидат социалистовреволюционеров, вовсю использовал свою репутацию участника революции 1905 г., который «первым поднял знамя восстания в Свеаборге». Большевики ставили под сомнение роль Циона:

Цион, быть может, имел некоторое отношение к предварительной подготовке этого восстания, но оно было поднято мучениками Емельяновым и Коханским, положившим жизнь свою за други свои. Эти офицеры, а также и казненные и замученные на каторге солдаты были подлинными руководителями Свеаборгского восстания, им подобает (!) вечная слава и вечная благодарность потомства, а не г. Циону, который во дни восстания не чуть ли один раз съездил на несколько часов в Свеаборг, куда он больше не возвращался, отправившись в Гельсингфорс засъестными припасами. Само собой разумеется, революционеры не обязаны во что бы то ни стало отдаваться в руки своих палачей. Но г. Цион в дни восстания не проявил того мужества, которое давало бы ему теперь приписывать славу главного руководителя Свеаборгского восстания. Цион в 1905 - 1906 гг. был сначала с.-д., но не поладив с подлинными партийными работниками, сделался эс-эром. Вообще это - страшный болтун и фантазер. ${ }^{56}$

В то же время и большевики подчеркивали особую революционную роль Свеаборга, и они льстили своим избирателям, культивируя особую, элитарную позицию. Но они обращались к прошлому, требуя, чтобы избиратели заняли самую радикальную позицию:

Свеаборжцы! В 1906 г. первыми в Финляндии загудели ваши пушки за свободу. Свеаборг занял почетное место в истории нашей революции. Снова льется кровь рабочих, солдат и матросов. Докажите, что в вас не умер еще дух вооруженного восстания! Поддержите партию пролетариата и крестьянской бедноты - партию большевиков. ${ }^{57}$

Политическая топография мест памяти 1905 г. создавалась в результате конфликтов разного уровня и разного характера.

Прежде всего радикально перечерчивалась та «карта» событий 10-12летней давности, которая создавалась старым режимом.

Другое измерение политической борьбы, связанное с политикой памяти, это противостояние оборонцев разного толка и радикальных социалистов. И в Севастополе, и в Гельсингфорсе инициатива проведения коммеморативных акций принадлежала умеренным политическим силам. Это было связано с рядом обстоятельств. После Февраля, в условиях двоевластия, умеренные социалисты все активнее становились важной составляющей «партии власти». Соответственно, именно им пришлось «изобретать традицию» нового режима. Со временем умеренные политические силы, социалисты и несоциалисты, испытывали все возрастающее давление со стороны большевиков и других

56. Прибой, Гельсингфорс, 1917, 5 (18) ноября.

57. Прибой, Гельсингфорс, 1917, 4 (17) ноября. 
радикальных социалистов. В этих условиях именно активная политика памяти была важным ресурсом конструирования революционной легитимности.

Однако умеренным социалистам и, тем более, оборонцам-несоциалистам, было сложно монополизировать память о революции 1905 года, права на нее возлагали и левые социалисты. «Места памяти», создававшиеся и «перестраивавшиеся» в ходе политических конфликтов 1917 года, вполне могли стать выгодным плацдармом для политических наступлений большевиков и их союзников, ресурсом для радикализации политического процесса.

Впоследствии память о революции 1905 года стала важным элементом политической культуры советского режима. Не только социалистыреволюционеры, А.Ф. Керенский, но даже и адмирал А.В. Колчак косвенно влияли на создание мифов, ритуалов и символов, успешно использовавшихся большевиками для легитимации своей власти.

Санкт-Петербургский Институт истории Российской Академии наук, Эвропейский университет в Санкт-Петербурге

boris_i_kol@mail.ru 